\title{
SISTEM SELF ASSESMENT, DAN PENGETAHUAN MEKANISME DALAM PEMUNGUTAN WAJIB PAJAK DI INDONESIA
}

\author{
Fariq Pramasta Iszanudin, Siti Aisyah, Akhmad Syafii Anwar
}

\begin{abstract}
ABSTRAKSI
Semua negara pasti memliki sistem perpajakan yang beda. Pajak sendiri berfungsi sebagai guna membiayai pengeluaran - perngeluaran, pajak juga bermanfaat untuk digunakan dalam melakukan pembangunan hingga membayar gaji pegawai negeri. Tujuan dari penelitian ini adalah guna mengedukasi masyarakat tentang sistem yang ada dalam pemungutan pajak serta mekanisme dalam pemungutan pajak tersebut. Jenis penelitian yang digunakan berdasarkan masalah yang diteliti adalah penelitian kualitatif. Pajak sendiri merupakan sumber penerimaan negara yang utama. Semakin hari peranan penerimaan pajak bagi pembiayaan umum atau negara semakin besar. Maka sistem pemungutan pajak adalah suatu cara yang dipakai untuk menghitung besarnya pajak yang perlu dibayarkan kepada negara. Hasil penelitian ini sistem pemungutan pajak di Indonesia sepenuhnya bersifat self assesment system. Serta Masalah sistem perpajakan yang berlaku di Indonesia dapat ditelusuri kembali ke rendahnya kesadaran hukum masyarakat Indonesia. Wajib pajak memanfaatkan peluang yang ditawarkan oleh sistem self-assessment ini. Undang-undang yang memperlakukan wajib pajak secara self assessment system kurang kesadaran hukum wajib pajak, lemahnya pengawasan, dan belum optimalnya penerapan sanksi bagi wajib pajak yang melanggarnya. Pengawasan sebelumnya belum berjalan maksimal, dan sanksi bagi Wajib Pajak yang ternyata melakukan atau melakukan pelanggaran perpajakan masih sangat lemah.
\end{abstract}

Kata kunci : sistem pemungutan, pengetahuan pajak, perpajakan

\begin{abstract}
Every country has a different tax system. Taxes themselves function as to finance expenses, taxes are also useful to be used in carrying out development to paying the salaries of civil servants. The purpose of this study is to educate the public about the existing system in tax collection and the mechanism in collecting the tax. The type of research used based on the problem under study is qualitative research. Tax itself is the main source of state revenue. The role of tax revenue for general or state financing is getting bigger day by day. So the tax collection system is a method used to calculate the amount of tax that needs to be paid to the
\end{abstract}


state. The results of this study are the tax collection system in Indonesia is fully selfassessment system. And the problem of the taxation system that applies in Indonesia can be traced back to the low legal awareness of the Indonesian people. Taxpayers take advantage of the opportunities offered by this self-assessment system. The law that treats taxpayers with a self-assessment system lacks legal awareness of taxpayers, lacks supervision, and has not yet optimally applied sanctions for taxpayers who violate them. Previous supervision has not run optimally, and sanctions for taxpayers who are found to have committed or committed tax violations are still very weak.

Keywords: collection system, tax knowledge, taxation

\section{PENDAHULUAN}

Pendapatan suatu pajak sangat berperan penting bagi kepentingan pembangunan Indonesia. Undang-Undang Republik Indonesia Nomor 28 Tahun 2007 Tentang Ketentuan Umum Dan Tata Cara Perpajakan telah menyebutkan defenisi pajak adalah kontribusi wajib kepada negara yang terutang oleh orang pribadi atau badan yang bersifat memaksa berdasarkan Undang-Undang, dengan tidak mendapatkan imbalan secara langsung dan digunakan untuk keperluan negara bagi sebesar - besarnya kemakmuran rakyat ${ }^{1}$.(Indonesia, 2007)

Pajak menurut Adrian Sutedi dalam bukunya yang berjudul Hukum Pajak adalah suatu perikatan yang timbul karena adanya undang-undang yang menyebabkan timbulnya kewajiban warga negara untuk menyetorkan sejumlah penghasilan tertentu kepada negara, negara mempunyai kekuatan untuk memaksa, dan uang pajak tersebut harus digunakan untuk penyelenggaraan pemerintahan. Dari pendekatan hukum ini menurut Adrian Sutedi memperlihatkan bahwa pajak yang dipungut harus berdasarkan undang-undang sehingga menjamin adanya kepastian hukum, baik bagi fiskus sebagai pengumpul pajak maupun wajib pajak sebagai pembayar pajak $^{2}$.(Indonesia, 2007)

Indonesia menerapkan Self Assessment System (SAS) sejak tahun 1983, yang sebelumnya memakai Official Assesment System (OAS). Berubahnya penggunaan OAS ke SAS dianggap sebagai reformasi yang besar karena OAS tidak melibatkan keaktifan Wajib Pajak dalam melaksanakan kewajiban perpajakan sedangkan SAS melibatkan peran keaktifan WP dalam penentuan besarnya pajak yang terutang dan melaporkan secara teratur jumlah

\footnotetext{
${ }^{1}$ Undang - Undang Nomor 28 Tahun 2007

${ }^{2}$ Adrian Sutedi, Hukum Pajak, Sinar Grafika, Jakarta, 2016, hal 1
} 
pajak yang terutang dan yang telah dibayar sebagaimana ditentukan dalam peraturan perundang-undangan perpajakan. Dengan customized organization lain, sistem ini memberi wewenang, kepercayaan, tanggungjawab kepada Wajib Pajak untuk menghitung, memperhitungkan, membayar, dan melaporkan sendiri besarnya pajak yang harus dibayar (Waluyo dan Ilyas, 2000:10)(Witono, 2016).

Dalam kaitannya dengan Wajib Pajak, kepatuhan dapat didefinisikan sebagai perilaku Wajib Pajak dalam memenuhi kewajiban perpajakannya sesuai dengan peraturan yang berlaku. Perilaku tersebut sangat dipengaruhi oleh motivasi. Biasanya motivasi akan berpengaruh terhadap intensitas perilaku (termotivasi, tanpa motivasi, dan apatis), dan kesesuaian dengan tujuan perilaku (efektif, tidak efektif) (Budiatmanto, 1999:48). Sedangkan Luigi Alberto Fronzoni (1999) menyatakan bahwa Kepatuhan dalam hukum pajak memiliki arti umum sebagai (1) melaporkan secara benar dasar pajak, (2) memperhitungkan secara benar kewajiban, (3) tepat waktu dalam pengembalian, (4) tepat waktu membayar jumlah dihitung. Dan Alm (1991) mendefinisikan kepatuhan sebagai pelaporan semua pendapatan dan pembayaran pajak secara keseluruhan yang sesuai dengan aplikasi hukum, peraturan dan keputusan hakim (dalam Palil 2005).(Witono, 2016) Salah satu unsur yang bisa ditekankan oleh aparat dalam meningkatkan kesadaran dan kepatuhan pajak adalah dengan cara menyosialisasikan peraturan pajak baik itu melalui penyuluhan, seruan moral baik dengan media board, baliho, maupun membuka situs peraturan pajak yang setiap saat bisa diakses Wajib Pajak. Sehingga dengan adanya sosialisasi tersebut pengetahuan Wajib Pajak terhadap kewajiban perpajakannya bertambah tinggi. Pengetahuan tentang peraturan perpajakan penting untuk menumbuhkan perilaku patuh, karena bagaimana mungkin Wajib Pajak disuruh patuh apabila mereka tidak mengetahui bagaimana peraturan perpajakan, artinya bagaimana Wajib Pajak disuruh untuk menyerahkan SPT tepat waktu jika mereka tidak tahu kapan waktu jatuh rhythm penyerahan SPT.

Selama ini, meskipun hukumnya telah mengalami perbaikan, yakni berlakunya Undang-Undang Nomor 28 Tahun 2007 tentang Perubahan Ketiga atas Undang-Undang Nomor 6 Tahun 1983 telah menciptakan sistem penilaian sendiri yang diatur oleh UndangUndang Nomor 6 Tahun 1983 akan terus diterapkan. Hak ini merupakan hukum makro dari berbagai ketentuan lain di bidang perpajakan. Secara umum, tujuan dari ketentuan ini adalah untuk menciptakan lebih banyak keadilan. Meningkatkan pelayanan kepada Wajib Pajak, memperkuat kepastian hukum dan penegakan hukum, mengantisipasi kemajuan teknologi informasi dan perubahan substantif hukum perpajakan. Selain itu, keahlian sistem perpajakan 
akan meningkat, administrasi perpajakan akan menjadi lebih transparan, dan kepatuhan sukarela wajib pajak akan meningkat.

Berbagai upaya pemerintah untuk meningkatkan penerimaan negara di bidang perpajakan, termasuk penyempurnaan undang-undang tentang ketentuan umum dan tata cara perpajakan, telah membawa undang-undang tersebut kepada sistem self assessment wajib pajak, partisipasi wajib pajak dan kesadaran cara pembayaran pajak. Padahal, berbagai penelitian yang dilakukan menunjukkan bahwa tingkat penetrasi di sektor perpajakan terletak pada penerapan sistem yang ada, karena kesadaran hukum Indonesia masih rendah. Wajib pajak membayar pajak yang kecil dan terus mencari celah untuk menghindari pajak yang tinggi

Tujuan dari penelitian ini adalah guna mengedukasi masyarakat tentang sistem yang ada dalam pemungutan pajak serta mekanisme dalam pemungutan pajak tersebut. Adapun kegunaan dari penelitian ini adalah sebagai berikut :

1 Bagi Pemerintah, hasil penelitian ini adalah untuk mengetahui sejauh mana pemahaman masyarakat dalam sistem ataupun pengetahuan mekanisme dalam pemungutan wajib pajak

2 Bagi Masyarakat, manfaat dari penelitian ini untuk mengetahui pemahaman masyarakat dalam sistem ataupun mekanisme dalam pemungutan wajib pajak

3 Bagi Peniliti, selanjutnya penelitian ini diharapkan menjadi salah satu referensi untuk bidang penelitian yang relevan.

\section{LANDASAN TEORI}

\section{Apa itu pajak?}

Pajak merupakan salah satu sumber keuangan pemerintah untuk penyelenggaraan pemerintahan. Pemungutan pajak telah lama dilakukan, mulai dari upeti wajib kepada raja dalam bentuk panen seluruh kerajaan hingga polanya masing-masing. Pada awalnya pemungutan pajak didasarkan pada aturan penguasa/raja, tetapi sekarang telah diubah dengan mengikutsertakan rakyat (wajib pajak) melalui aturan antara penguasa (pemerintah) dan wakilnya.

Soemitro (1990 : 5) pajak adalah iuran rakyat kepada kas negara berdasarkan Undangundang (yang dapat dipaksakan) dengan tidak mendapatkan jasa timbal (kontraprestasi), yang langsung dapat ditunjukkan dan yang digunakan untuk membayar pengeluaran umum.

Mardiasmo (1997:1) pengertian pajak adalah Iuran rakyat kepada kas negara berdasarkan undang-undang (yang dapat dipaksakan) dengan tiada mendapatkan imbalan jasa 
(kontra prestasi) yang langsung dapat ditunjukkan dan yang digunakan untuk membayar pengeluaran umum. (Rachmad Gesah Mukti Prabowo, SE. Ak, 2014)

Tujuan pemungutan pajak negara adalah untuk memenuhi kebutuhan keuangan negara untuk belanja negara sehingga penyelenggaraan negara dapat tetap berjalan. Dari pengertian di atas, sistem yang terkait dengan definisi pajak dapat disimpulkan sebagai berikut.

1. Pajak dipungut sesuai dengan undang-undang dan peraturan pelaksanaannya.

2. Anda dapat menegakkan properti itu.

3. Tidak ada pengembalian langsung dari pemerintah.

4. Dikumpulkan oleh pemerintah pusat dan daerah.

5. Pajak dialokasikan untuk pengeluaran pemerintah. (Prabowo, 2014)

\section{Apa fungsi dari pajak?}

Ada dua fungsi pajak. Itu adalah:

1. Pajak fungsional Budgetair

Memberikan kontribusi terbesar terhadap penerimaan negara, yaitu sekitar 60-70 persen dari penerimaan pajak setara dengan APBN. Oleh karena itu, pajak merupakan sumber pendapatan bagi negara untuk menutupi biaya hidup dan pembangunannya. Contoh: Penerimaan pajak sebagai sumber pendapatan APBN.

2. Fungsi Mengatur (Regulerend)

Pajak berfungsi sebagai alat untuk mengatur masyarakat atau melaksanakan kebijakan pemerintah dalam bidang sosial dan ekonomi. Contoh:

a Memberikan insentif pajak (tax holiday) untuk mendorong peningkatan investasi di dalam negeri.

b Pengenaan pajak yang tinggi terhadap minuman keras untuk mengurangi konsumsi minuman keras.

c Pengenaan tarif pajak nol persen atas ekspor untuk mendorong peningkatan ekspor produk dalam negeri.

Dalam pandangan Richard Burton dan Wirawan B. Ilyas ${ }^{3}$ (Setiyaji, 2005) terdapat pula fungsi lain dari pajak yang saat ini mengemuka, yaitu

1. Fungsi Demokrasi

Fungsi demokrasi menyatakan bahwa pajak merupakan salah satu penjelmaan dan pembangunan demi kemaslahatan manusia. Sebagai implementasinya, pajak memiliki

\footnotetext{
${ }^{3}$ Richard Burton dan Wirawan B. Ilyas Hal9
} 
konsekuensi untuk memberikan hak - hak timbal balik yang meskipun tidak diterima langsung, tetapi diberikan kepada warga negara pembayar pajak.

2. Fungsi Redistribusi

Yaitu mengimplementasikan unsur pemerataan dan keadilan dalam masyarakat. Bila pajak diterapkan dengan baik maka dapat dipastikan terjadi beberapa dampak pajak terhadap perekonomian dan berbagai aspeknya.

Secara umum struktur ekonomi (tidak termasuk pajak) terdiri dari pendapatan nasional, konsumsi dan tabungan. Jika semua tabungan Anda dihabiskan untuk investasi, tidak ada inflasi atau deflasi. Namun, tidak semua tabungan digunakan untuk investasi dan dapat menyebabkan resesi, deflasi, dan pengangguran. Atau sebaliknya, tingkat tabungan dan investasi yang menyebabkan kegairahan ekonomi inflasi rendah.

\section{Sistem Pemungutan Pajak}

Sistem pemungutan pajak dapat dibagi menjadi empat jenis berikut.

\section{Official Assesment System}

Penagihan pajak yang memberdayakan pemungut pajak untuk menentukan besarnya pajak yang harus dibayar oleh orang pribadi. Dalam sistem ini, wajib pajak pasif dan menunggu otoritas pajak menerbitkan surat ketetapan pajak. Besarnya kewajiban perpajakan orang pribadi baru diketahui setelah surat ketetapan pajak diterbitkan.

\section{Semiself Assesment System}

Sistem pemungutan pajak yang memungkinkan otoritas pajak dan wajib pajak untuk menentukan jumlah pajak yang harus dibayar oleh seseorang. Berdasarkan sistem ini, pada setiap awal tahun pajak, wajib pajak menentukan jumlah pajak yang harus dibayar pada tahun berjalan. Ini adalah pembayaran angsuran yang harus dibayar oleh wajib pajak untuk dirinya sendiri. Pada akhir tahun pajak, kantor pajak akan menentukan kewajiban pajak yang sebenarnya berdasarkan data yang dilaporkan oleh wajib pajak.

\section{Withholding System}

Adalah sistem pemungutan pajak yang memungkinkan pihak ketiga untuk memotong atau memungut jumlah pajak yang belum dibayar. Pihak ketiga yang ditunjuk akan menyetorkannya dan melaporkannya ke kantor pajak. Otoritas pajak dan wajib pajak tidak aktif dalam sistem ini. Otoritas pajak hanya bertanggung jawab untuk memantau pelaksanaan pemotongan atau pemungutan oleh pihak ketiga.

\section{Self Assement System}

Sistem pemungutan pajak adalah sistem pemungutan pajak yang memberikan kewenangan penuh kepada wajib pajak untuk menghitung, menghitung, menyetor, dan melaporkan jumlah 
kewajiban perpajakannya. Dengan sistem ini, wajib pajak akan aktif selama otoritas pajak tidak campur tangan dalam menentukan pajak mana yang harus dibayar oleh orang pribadi, kecuali jika wajib pajak melanggar peraturan yang berlaku.

Pemungutan pajak merupakan pendapatan suatu masyarakat, bukan mengurangi pendapatan atau kekayaan seseorang, yang dikembalikan kepada masyarakat melalui pengeluaran-pengeluaran normal dan pembangunan dan pada akhirnya kepada seluruh masyarakat untuk memberi manfaat bagi masyarakat, baik dibayar maupun tidak.

Pajak memegang peranan yang sangat penting dalam kehidupan suatu negara, terutama dalam perkembangannya. Hal ini karena pajak merupakan sumber penerimaan pemerintah untuk membiayai seluruh pengeluaran, termasuk pengeluaran pembangunan. Saat memungut pajak, harus jelas siapa dan apa pajaknya. Oleh karena itu, mereka harus dikelola dengan baik dan benar untuk memastikan konsistensi data wajib pajak. Selain itu, tarif pajak harus ditentukan sesuai dengan peraturan yang berlaku saat itu. Hal ini memungkinkan wajib pajak untuk membayar pajak mereka secara teratur dan hati-hati. Subjek perpajakan adalah orang pribadi, badan hukum, atau badan hukum lain yang memenuhi syarat subjektif, yaitu bertempat tinggal di Indonesia atau bertempat tinggal tetap. Suatu objek kena pajak baru menjadi wajib pajak jika memenuhi syarat objektif. Yang kena pajak itulah yang kena pajak. Mengingat pentingnya dan strategisnya suatu objek kena pajak, maka undang-undang perpajakan kita selalu secara tegas menyatakan apa saja jenis objek kena pajak tersebut, yang berkaitan dengan apakah objek tersebut kena pajak atau tidak.

\section{METODE PENELITIAN}

\section{Jenis Penelitian dan Gambaran dari Obyek Penelitian}

Jenis penelitian yang digunakan berdasarkan masalah yang diteliti adalah penelitian kualitatif. Penelitian kualitatif adalah penelitian yang membahas tentang gagasan, persepsi, pendapat, dan keyakinan orang-orang yang akan diteliti, yang kesemuanya tidak dapat diukur dengan angka. Penelitian desktiptif adalah sebuah penelitian yang bertujuan untuk memberikan atau menjabarkan suatu keadaan atau fenomena yang terjadi saat ini dengan menggunakan prosedur ilmiah untuk menjawab masalah secara actual (Sugiyono, 2012 : 22). Penelitian deskriptif yaitu mengumpulkan data berdasarkan faktor- faktor yang menjadi pendukung terhadap objek penelitian, kemudian menganalisa faktor- faktor tersebut untuk dicari peranannya (Arikunto, 2010: 151).(Hadi, 2017)

Metodologi desain yang digunakan dalam penelitian ini adalah analisis kualitatif yang bertujuan untuk menggabungkan sejumlah besar data mentah dengan informasi yang dapat 
diinterpretasikan. Dalam penelitian kualitatif perangkat atau alat penelitiannya adalah peneliti itu sendiri, tetapi dalam penelitian ini digunakan beberapa alat lain yaitu pedoman wawancara. Panduan wawancara yang khusus dibuat untuk investigasi ini digunakan untuk memperoleh gambaran umum dan rinci tentang sistem pemungutan pajak di Indonesia.

\section{PEMBAHASAN}

\section{Sejarah Perpajakan di Indonesia}

Sejak zaman kolonial telah dilakukan pemungutan pajak oleh setiap rakyat kepada pemerintahan yang berkuasa, pungutan seperti itu dipersembahkan kepada raja sebagai wujud rasa hormat kepada raja, pungutan itu merupakan suatu upeti (pemberian secara Cuma-Cuma) dan harus dibayarkan tidak boleh tidak. Pada masa itu pemberian upeti atau pajak yang diberikan bisa berupa uang, ternak ataupun hasil pertanian, pemberian-pemberian itu diperuntukkan untuk kepentingan pribadi Raja atau penguasa.

Dalam perkembangannya, upeti yang diberikan oleh rakyat tidak lagi untuk kepentingan raja semata, tetapi juga sudah mengarah pada kepentingan rakyat. Artinya, pemberian yang dilakukan oleh rakyat kepada raja digunakan untuk kepentingan umum seperti menjaga keamanan, membuat jalan, memperbaiki pengairan persawahan, serta untuk kepentingan sosial lainnya.

Seiring perkembangan dalam masyarakat, maka dibuatlah suatu aturan yang lebih baik dan bersifat memaksa berkaitan dengan sifat upeti (pemberian) tersebut dengan memperhatikan unsur keadilan. Guna memenuhi unsur keadilan inilah maka rakyat diikut sertakan dalam membuat berbagai aturan dalam pemungutan pajak, yang nantinya akan dikembalikan juga hasilnya untuk kepentingan rakyat itu sendiri ${ }^{4}$.

Pada awal kemerdekaan, undang-undang darurat diberlakukan No. 12 tahun 1950, yang menjadi dasar pengenaan pajak kendaraan bermotor (komoditas) 1951 digantikan oleh pajak penjualan. pemungutan pajak 1951 Sistematis dan permanen, dimulai dengan pemungutan pajak properti Itu sudah ada di zaman kolonial. Pajak ini disebut "Landrent" (sewa tanah). Dari Gubernur Inggris. Pada zaman penjajahan Belanda disebut "Landrente". Peraturan sewa diberlakukan pada tahun 1907 dan kemudian pada tahun diubah dan ditambah dengan Ordonansi Landrente. Pada tahun 1932, dikeluarkan Ordonansi Pajak Kekayaan (PKk) yang beberapa kali diubah dengan UndangUndang Nomor 24 Tahun1964.

\footnotetext{
${ }^{4}$ Wirawan B. Ilyas dan Richard Burton, Hukum Pajak Teori, Analisis, dan Perkembangannya, Salemba Empat, Jakarta, 2013, Hal. 1
} 
Pada tahun 1983 pemerintah bersama-sama dengan Dewan Perwakilan Rakyat (DPR) sepakat melakukan reformasi undang-undang perpajakan yang ada dengan mencabut semua undang-undang yang ada dan mengundangkan lima (5) paket undang-undang perpajakan yang sifatnya lebih muda dipelajari dan diperaktikkan serta tidak menimbulkan duplikasi dalam hal pemungutan pajaknya dan unsur keadilan menjadi lebih diutamakan, bahkan sistem perpajakan yang semula official assesment diubah menjadi self assesment. Kelima undangundang tersebut adalah :

1. UU No. 6 Tahun 1983 tentang Ketentuan Umun dan Tata Cara Perpajakan (KUP);

2. UU No. 7 Tahun 1983 tentang Pajak Penghasilan (PPh);

3. UU No. 8 Tahun 1983 tentang Pajak Pertambahan Nilai atas Barang dan Jasa dan Pajak Penjualan atas Barang Mewah (PPN dan PPnBM);

4. UU No. 12 Tahun 1985 tentang Pajak Bumi dan Bangunan (PBB); dan

5. UU No. 13 Tahun 1985 tentang Bea Materai (BM).

Dengan diberlakukannya kelima undang-undang tersebut, semua lapisan masyarakat tentunya diharapkan turut berpartisipasi dan dapat mengerti akan kewajibannya untuk membayar pajak sesuai dengan Sistem self assesment yang berlaku sejak 1983 berdasarkan reformasi undang-undang perpajakan tersebut.

Pemungutan pajak adalah perwujudan pengabdian dan peran serta wajib pajak untuk secara langsung bersama sama melaksanakan wajib pajak. Seorang warga negara tentunya meiliki beban pajak yang harus dibayarkan kepada negara untuk kelangsungan kehidupan bernegara. Daari pembayaran pajak tersebut oleh negara digunakan untuk membiayai seluruh pengeluaran - pengeluaran. Tentunya pajak juga bermanfaat untuk melakukan pembangunan samapi membayar gaji pegawai negeri.

Teori yang mendukung untuk pemungutan pajak diungkapkan oleh (Brotodihardjo, 1993) yang memberikan pembenaran kepada negara untuk berhak memungut pajak dari rakyat

\section{Teori Asuransi}

Negara berkewajiban melindungi orang dan/atau warganya guna menjamin keselamatan segala kepentingan, jiwa dan harta benda. Oleh karena itu, pembayaran pajak dianggap atau setara dengan pembayaran premi, karena dijamin perlindungan negara.

\section{Teori Kepentingan}

Teori ini menyatakan bahwa pengenaan pajak atas seluruh penduduk harus didasarkan pada kepentingan masing-masing orang dalam suatu misi negara/pemerintah (bermanfaat baginya), termasuk perlindungan terhadap nyawa orang-orang tersebut dan harta bendanya. 
menekankan bahwa itu tidak akan terjadi. Pembayaran pajak terkait dengan kepentingan orang-orang ini di negara. Semakin banyak bunga yang Anda miliki di negara bagian, semakin tinggi pajak yang dibayarkan.

\section{Sustainability Theory}

Sustainability Theory menyimpulkan bahwa dasar keadilan dalam pemungutan pajak adalah pelayanan negara bagi rakyat, yaitu perlindungan jiwa dan harta benda. Untuk memenuhi manfaat tersebut, ada biaya yang harus ditanggung warga berupa pajak. Inti dari teori ini adalah prinsip perpajakan. Artinya, tekanan pajak harus sama untuk semua orang. Pajak harus dibayar sesuai dengan kelangsungan hidup seseorang, dan untuk mengukur keberlanjutan, seseorang dapat fokus pada pendapatan, aset, dan pengeluaran seseorang dan memperhatikan ukuran keluarga, saya bisa melakukannya.

\section{Teori Bhakti}

Teori ini didasarkan pada konsep organisasi nasional dan mengajarkan bahwa negara sebagai organisasi memiliki kewajiban untuk mengurus kepentingan umum. Negara memiliki kenaikan pajak yang tidak terbatas dan warga negara harus membayar pajak sebagai bukti pengabdian kepada negara. Oleh karena itu, dasar hukum perpajakan adalah hubungan antara pemerintah daerah dan negara bagian.

\section{Teori Asas Daya Beli}

Menurut teori ini, fungsi pemungutan pajak, yaitu mengambil daya beli dari rumah tangga masyarakat untuk rumah tangga negara, kemudian menyalurkan kembali ke masyarakat dengan maksud untuk memelihara kehidupan masyarakat dan untuk membawa ke arah tertentu, yaitu kesejahteraan. Jadi, penyelenggaraan kepentingan masyarakat inilah yang dianggap sebagai dasar keadilan pemungutan pajak, bukan kepentingan individu, bukan pula kepentingan negara, melainkan kepentingankepentingan masyarakat yang meliputi keduanya.

Dalam suatu negara tentunya memiliki sistem pemungutan pajak yang berbeda - beda. Sistem pemungutan pajak sendiri adalah suatu cara yang digunakan atau dipakai untuk menghitung besarnya pajak yang perlu dibayarkan kepada negara.

Di Indonesia sendiri sampai sekarang menggunakan Self Assesment System. Dalam penerapannya atau pelaksanaanya dapat dilihat dalam pasal 12 UU KUP yang pada ayat (1) menyatakan bahwa setiap Wajib Pajak wajib membayar pajak yang terutang sesuai dengan ketentuan peraturan perundang-undangan perpajakan, dengan tidak menggantungkan pada adanya surat ketetapan pajak. Kemudian pada ayat (2) disebutkan bahwa jumlah pajak yang terutang menurut surat pemberitahuan (SPT) yang disampaikan oleh Wajib Pajak adalah jumlah pajak yang terutang sesuai dengan ketentuan peraturan perundang-undangan 
perpajakan. Dan pada ayat (3) apabila Direktur Jendral Pajak mendapatkan bukti jumlah pajak yang terutang menurut SPT sebagaimana dimaksud pada ayat (2) tidak benar, Direktur Jendral Pajak menetapkan jumlah pajak yang terutang ${ }^{5}$.

Selain itu, uraian Pasal 35A UU KKR lebih menekankan pada data dan informasi terkait perpajakan dari pemerintah sebagai bagian dari pemantauan kepatuhan kewajiban perpajakan melalui pengenalan sistem self-assessment. Lembaga, lembaga, asosiasi dan pihak lain disediakan oleh direktorat pajak yang sangat dibutuhkan. Data dan informasi tersebut adalah data yang menggambarkan kegiatan atau usaha yang bersifat atau badan, alur usaha, pendapatan dan kekayaan. Tentu saja, ada banyak masalah dengan penerapan sistem penilaian mandiri ini. Banyaknya tindakan Wajib Pajak yang melanggar aturan yang berlaku di bidang perpajakan. Pelanggaran ini biasanya berupa penggelapan, penipuan, pemalsuan, dll.

Dalam pelaksanaan sistem self assesment ini tentunya memiliki banyak persoalan. Banyaknya perbuatan wajib pajak yang melanggar aturan yang berlaku dibidang perpajakan, pelanggaran ini biasanya berupa penggelapan, penipuan, pemalsuan dan sebagainya.

Di dalam undang-undang perpajakan nomor 16 tahun 2000 tentang perubahan kedua atas undang-undang nomor 6 tahun 1983 tentang ketentuan umum dan tata cara perpajakan, diatur beberapa pasal yang menjelaskan hal yang berkaitan dengan terjadinya dan sanksisanksi atas kejahatan/pidana perpajakan, yakni dalam pasal 38 sampai dengan pasal $42^{6}$, yang oleh Adrian Sutedi mengungkapkan beberapa kejahatan/tindak pidana perpajakan yang mungkin saja terjadi dikarenakan :

a Adanya unsur kealpaan (yaitu ketidaksengajaan, kelalaian, ketidakhati-hatian, kurang mengindahkan kewajibannya dalam perpajakan), ini sifatnya masih pelanggaran perpajakan; Adapun unsur kealpaan dalam perpajakan terjadi dalam hal berikut :

1) Tidak menyampaikan surat pemberitahuan (SPT) ke Direktorat Jendral Pajak.

2) Menyampaikan SPT, tetapi isinya tidak benar/tidak lengkap/melampirkan keterangan yang isinya tidak benar atas kealpaan yang menimbulkan kerugian negara, pelakunya dapat dipidana dengan pidana kurungan paling lama 1 tahun, dan atau denda paling tinggi 2 kali jumlah pajak terutang.

b Adanya unsur kesengajaan (dengan sengaja melakukan pelanggaran atas ketentuan perundang-undangan perpajakan), hal ini sifatnya sudah kejahatan/ pidana perpajakan.

\footnotetext{
${ }^{5}$ Undang Undang Nomor 28 Tahun 2007

${ }^{6}$ Undang Undang Republik Indonesia Tahun 2000
} 
1) Tidak mendaftarkan diri sebagai WP/PKP atau menyalahgunakan / menggunakan tanpa hak NPWP/ Pengukuhan PKP.

2) Tidak menyampaikan SPT.

3) Menyampaikan SPT/keterangan yang isinya tidak benar atau tidak lengkap.

4) Menolak untuk dilakukan pemeriksaan.

5) Memperlihatkan pembukuan, pencatatan, atau dokumen lain yang palsu/dipalsukan seolah-olah benar.

6) Tidak menyelenggarakan pembukuan/pencatatan, tidak memperlihatkan atau tidak meminjamkan buku, catatan, dokumen lainnya.

7) Tidak menyetorkan pajak yang telah dipotong/dipungut.

Atas unsur kesengajaan diatas yang menimbulkan kerugian negara, pelakunya dapat dipidana dengan pidana kurungan paling lama 6 tahun, dan atau denda paling tinggi 4 kali jumlah pajak terutang.

Sebelum masuk ke dalam mekanisme pemungutan pajak, ada tata cara yang dilakukan dalam pemungutan pajak yaitu dengan stelsel pajak, antara lain :

a Stelsel nyata (stelsel riil)

Menurut Real stelsel, perpajakan didasarkan pada tujuan atau penghasilan yang sebenarnya dicapai, sehingga penilaian hanya dapat dilakukan pada akhir tahun pajak, yaitu setelah mengetahui penghasilan yang sebenarnya. Keuntungan dari sistem ini adalah pajak yang dipungut lebih realistis, tetapi kerugiannya adalah periode (setelah mengetahui pendapatan riil) sedangkan negara membutuhkan penerimaan pajak untuk mempertahankan biaya keuangan setahun penuh. akhir dari.

b Penerimaan Stelsel (Stelsel fiktif)

Menurut sistem penerimaan, pemungutan pajak didasarkan pada penerimaan yang diatur secara hukum. Misalnya, pendapatan satu tahun sama dengan pendapatan tahun sebelumnya, sehingga jumlah pajak yang dibayar dalam tahun pajak berjalan dapat ditentukan pada awal tahun pajak. Keuntungan dari sistem ini adalah Anda dapat membayar pajak dalam tahun ini tanpa menunggu akhir tahun, dan meskipun pemerintah dapat menghasilkan pendapatan pajak sepanjang tahun, namun kelemahannya adalah jumlah pembayaran pajak yang kecil. Anda akan dibayar berdasarkan persyaratan yang sebenarnya atau tidak realistis.

c Gaya campuran

Stelsel ini adalah kombinasi dari stelsel yang sebenarnya dan stelsel yang diasumsikan. Jumlah pajak dihitung berdasarkan taksiran jumlah pajak pada awal tahun dan disesuaikan 
kembali dengan jumlah pajak sebenarnya pada akhir tahun. Apabila jumlah pajak menurut stelsel nyata lebih besar daripada pajak menurut stelsel anggapan maka Wajib Pajak harus menambah. Sebaliknya, jumlah pajak menurut stelsel nyata lebih kecil daripada menurut stelsel anggapan, maka kelebihannya dapat dimintai kembali (restitusi) atau dikompensasi pada periode berikutnya.

Pembayaran pajak merupakan salah satu tahapan siklus hak dan kewajiban (WP) wajib pajak. Di bawah sistem penilaian sendiri, wajib pajak wajib menghitung, membayar, dan mengungkapkan pembayaran pajaknya. Mekanisme pembayaran pajak dapat dibagi menjadi empat jenis: (1) Bayar pajak yang harus Anda bayar. (2) Pemotongan pajak oleh pihak lain dan pembayaran Pajak Penghasilan (PPh) dengan pemungutan. (3) Pembayaran PPN kepada penjual atau penyedia jasa atau pihak yang ditunjuk pemerintah. (4) Pembayaran pajak lainnya. Yang pertama adalah membayar pajak sendiri, termasuk angsuran pajak penghasilan bulanan ( $\mathrm{PPh}$ Pasal 25) dan pembayaran dasar pajak penghasilan satu tahun (PPh Pasal 29). Angsuran pajak penghasilan bulanan adalah pembayaran pajak penghasilan angsuran. Hal ini dimaksudkan untuk meringankan beban WP dalam melunasi pajak yang terutang dalam satu tahun pajak. WP diwajibkan untuk mengangsur pajak yang akan terutang pada akhir tahun dengan membayar sendiri angsuran pajak tersebut setiap bulan.

Khusus, bagi WP Orang Pribadi yang sumber penghasilannya dari usaha dan pekerjaan bebas, pembayaran angsuran PPh Pasal 25 terbagi atas 2 yaitu Angsuran PPh Pasal 25 bagi WP Orang Pribadi Pengusaha Tertentu (OPPT) dan Angsuran PPh Pasal 25 bagi WP Orang Pribadi Selain Pengusaha Tertentu (OPSPT). Yang dimaksud dengan WP OPPT adalah WP Orang Pribadi yang melakukan kegiatan usaha penjualan barang baik secara grosir maupun eceran dan usaha penyerahan jasa, yang mempunyai satu atau lebih tempat usaha termasuk yang memiliki tempat usaha yang berbeda dengan tempat tinggal. Angsuran PPh Pasal 25 bagi WP OPPT adalah $0,75 \%$ dikali jumlah peredaran usaha (omzet) setiap bulan dari masingmasing tempat usaha.

Sedangkan angsuran PPh Pasal 25 bagi WP OPSPT, yaitu orang pribadi yang melakukan kegiatan usaha tanpa melalui tempat usaha misalnya sebagai pekerja bebas atau sebagai karyawan, maka angsuran PPh Pasal 25nya adalah Penghasilan Kena Pajak (PKP) SPT tahun pajak sebelumnya dikali Tarif PPh Pasal 17 ayat (1) huruf a UndangUndang Pajak Penghasilan (UU PPh) dibagi 12 bulan. Sedangkan bagi WP Badan, besarnya pembayaran angsuran PPh Pasal 25 yang terutang diperoleh dari PKP dikalikan dengan tarif PPh yang diatur di Pasal 17 ayat (1) huruf b UU PPh. Tarif Pasal 17 ayat (1) huruf b dan ayat (2a) UU PPh adalah 25\%. Khusus untuk WP Badan yang peredaran bruto setahun sampai dengan lima 
puluh miliar rupiah mendapat fasilitas berupa pengurangan tarif sebesar $50 \%$ dari tarif pasal 17 ayat (1) huruf b dan ayat (2a) UU PPh, yang dikenakan atas PKP dari peredaran bruto sampai dengan Rp4,8 miliar.

Selanjutnya untuk pembayaran kekurangan $\mathrm{PPh}$ selama setahun ( $\mathrm{PPh}$ Pasal 29) dilakukan sendiri oleh WP pada akhir tahun pajak apabila pajak terutang untuk suatu tahun pajak lebih besar dari jumlah total pajak yang dibayar sendiri (angsuran PPh Pasal 25) dan pajakpajak yang dipotong atau dipungut pihak lain sebagai kredit pajak. Mekanisme pembayaran pajak yang kedua adalah membayar $\mathrm{PPh}$ melalui pemotongan dan pemungutan oleh pihak lain (PPh Pasal 4 (2), PPh Pasal 15, PPh Pasal 21, 22, dan 23, serta PPh Pasal 26). Pihak lain disini adalah sumber pendapatan, pemberi kerja, atau pihak lain yang ditunjuk atau ditunjuk oleh pemerintah.

Kedua, mekanisme pembayaran pajak yang ketiga adalah membayar PPN kepada penjual, penyedia jasa, atau pihak yang ditunjuk pemerintah. Tarif PPN adalah 10\% dari harga jual atau tukar, harga ekspor, atau nilai lainnya.

Dan terakhir, merupakan prosedur pembayaran pajak-pajak lainnya, mencakup pembayaran PBB yaitu pelunasan dari Surat Pemberitahuan Pajak Terutang (SPPT), \& pembayaran Bea Meterai. Untuk wilayah Jakarta \& wilayah eksklusif lainnya, pembayaran PBB telah bisa dilakukan menggunakan memakai ATM pada bank-bank eksklusif. Tarif PBB terdiri berdasarkan dua tarif yaitu (1) 1/1000 berdasarkan Nilai Jual Objek Pajak (NJOP) spesifik buat NJOP-nya kurang berdasarkan Rp1 miliar \& (dua) dua/1000 berdasarkan Nilai Jual Objek Pajak (NJOP) spesifik buat yg NJOP-nya kurang berdasarkan Rp1 miliar. Pembayaran Bea Meterai dipakai menjadi pelunasan pajak atas dokumen. Pelunasannya dilakukan menggunakan memakai benda meterai berupa meterai tempel atau kertas bermeterai atau menggunakan alternatif misalnya memakai mesin teraan. Meterai tempel yg terutang buat dokumen yang menyebut jumlah (kuitansi) pada atas Rp250.000 hingga menggunakan Rp1 juta merupakan Rp3 ribu. Untuk dokumen yg menyebut jumlah pada atas Rp1 juta \& surat-surat perjanjian terutang meterai tempel sebanyak Rp6 ribu.

Keempat jenis prosedur pembayaran pajak sentra pada atas, adalah kewajiban WP pada membayar pajak. Lalu bagaimana apabila WP lebih membayar pajak? Maka WP bisa menikmati hak WP atas Kelebihan Membayar Pajak. Yaitu WP memiliki hak buat menerima pulang kelebihan tadi apabila pajak yg terutang buat suatu tahun pajak ternyata lebih mini berdasarkan jumlah kredit pajak, atau menggunakan istilah lain pembayaran pajak yg dibayar atau dipotong atau dipungut lebih akbar berdasarkan yg seharusnya terutang. Pengembalian 
kelebihan pembayaran pajak bisa diberikan pada saat 12 bulan semenjak surat permohonan diterima secara lengkap. Untuk WP masuk kriteria WP Patuh, pengembalian kelebihan pembayaran pajak bisa dilakukan paling lambat tiga bulan buat PPh \& 1 bulan buat PPN semenjak permohonan diterima. Perlu diketahui pengembalian ini dilakukan tanpa pemeriksaan. WP bisa melakukan permohonan pengembalian kelebihan pembayaran pajak melalui 2 cara yaitu melalui Surat Pemberitahuan (SPT), \& menggunakan mengirimkan surat permohonan yg ditujukan pada Kepala KPP. Jika Direktorat Jenderal Pajak (DJP) terlambat mengembalikan kelebihan pembayaran yg semestinya dilakukan, maka WP berhak mendapat bunga dua\% per bulan maksimum 24 bulan.

Dalam suatu sistem pemungutan pajak tentunya ada sebuah mekanisme dalam pemungutan wajib pajak di Indonesia, mulai dari Pajak Penghasilan, Pajak Bumi dan Bangunan, Pajak Pertambahan Nilai, Pajak Penjualan atas Barang Mewah, Bea Materai. Pajak Bumi dan Bangunan yaitu pajak yang dikenakan terhadap obyek pajak berupa bumi dan atau bangunan. Obyek Pajak Bumi dan Bangunan adalah bumi/tanah dan bangunan. Sedangkan subyek Pajak Bumi dan Bangunan adalah orang atau suatu badan yang secara nyata mempunyai suatu hak atas bumi dan atau memperoleh manfaat atas bangunan. Untuk itu supaya lebih jelas dalam memahami mekanisme dalam pemungutan pajak, kami akan memberikan beberapa mekanisme dari pemungutan pajak PPN dan PPnBM.

Mekanisme pemungutan PPN sesuai dengan PMK Nomor 85/PMK.03/2012 tanggal 06 Juni 2012 yang berlaku efektif mulai 1 Juli 2012 adalah $^{7}$ :

1 Mekanisme pemungutan PPN yang pertama dan wajib adalah rekanan wajib membuat faktur pajak dan surat setoran pajak (SSP) atas setiap penyerahan BKP dan/atau JKP kepada BUMN.

2 Mekanisme pemungutan PPN yang kedua adalah faktur pajak sebagaimana dimaksud pada angka 1 dibuat sesuai dengan ketentuan di bidang perpajakan.

3 Ketiga adalah SSP sebagaimana dimaksud pada angka 1 diisi dengan membubuhkan NPWP serta identitas rekanan, tetapi penandatanganan SSP dilakukan oleh BUMN sebagai penyetor atas nama rekanan.

4 Keempat adalah dalam hal penyerahan BKP selain terutang PPN juga terutang PPnBM maka rekanan harus mencantumkan juga jumlah PPnBM yang terutang pada faktur pajak.

\footnotetext{
${ }^{7}$ PMK Nomor 85/PMK.03/2012
} 
5 Kelima adalah faktur pajak dibuat dalam rangkap 3 dengan peruntukkan sebagai berikut : lembar kesatu untuk BUMN, lembar kedua untuk rekanan, dan lembar ketiga untuk BUMN yang dilampirkan pada SPT Masa PPN bagi pemungut PPN.

6 Keenam adalah SSP sebagaimana dimaksud pada angka 1 dibuat dalam rangkap 5 dengan peruntukkan sebagai berikut : lembar kesatu untuk rekanan, lembar kedua untuk KPPN melalui Bank Persepsi atau Kantor Pos, lembar ketiga untuk rekanan yang dilampirkan pada SPT Masa PPN, lembar keempat untuk Bank Persepsi atau Kantor Pos, dan lembar kelima untuk BUMN yang dilampirkan pada SPT Masa PPN bagi Pemungut PPN.

7 Mekanisme Pemungutan PPN yang terakhir adalah faktur Pajak dan SSP merupakan bukti pemungutan dan penyetoran PPN atau PPN dan PPnBM.

\section{Mekanisme pelaporan PPN adalah :}

Pelaporan dilakukan setiap bulan dan laporan disampaikan ke KPP tempat BUMN terdaftar paling lama akhir bulan berikutnya setelah berakhirnya masa pajak dengan menggunakan formulir "Surat Pemberitahuan Masa PPN bagi Pemungut PPN" dan dilampiri dengan faktur pajak lembar ke-3 dan Surat Setoran Pajak (SSP) lembar ke-5 dalam hal terdapat pemungutan Pajak Pertambahan Nilai atau Pajak Pertambahan Nilai dan Pajak Penjualan atas Barang Mewah.

\section{Pemungutan Pajak Pertambahan Nilai dan Pajak Penjualan atas Barang Mewah dilakukan paling lambat :}

a Pada akhir bulan berikutnya setelah bulan terjadinya penyerahan Barang Kena Pajak dan/atau Jasa Kena Pajak dalam hal pembayaran diterima setelah akhir bulan berikutnya setelah bulan penyerahan Barang Kena Pajak dan/atau Jasa Kena Pajak; atau 6

b Pada saat melakukan pembayaran dalam hal :

1 Pembayaran terjadi sebelum akhir bulan berikutnya setelah bulan penyerahan Barang Kena Pajak dan/atau Jasa Kena Pajak;

2 Pembayaran dilakukan sebelum penyerahan Barang Kena Pajak dan/atau Jasa Kena Pajak; atau

3 Pembayaran dilakukan pada saat yang sama dengan saat penyerahan Barang Kena Pajak dan/atau Jasa Kena Pajak. 
Mekanisme Pemungutan PPnBM kendaraan bermotor Berdasarkan KMK Nomor 355/KMK.03/2003 jo. KEP- 229/PJ/2003 diatur sebagai berikut ${ }^{8}$ :

1. PPnBM dikenakan atas :

> Impor kendaraan CBU (Completely Built-Up) berupa kendaraan pengangkutan orang sampai dengan 15 orang termasuk pengemudi, kendaraan double cabin, kendaraan khusus, dan kendaraan bermotor beroda dua dengan kapasitas isi silinder lebih dari $250 \mathrm{CC}$;

$>$ Penyerahan kendaraan hasil perakitan/produksi di dalam Daerah Pabean berupa kendaraan pengangkutan orang sampai dengan 15 orang termasuk pengemudi, kendaraan double cabin, kendaraan khusus, dan kendaraan bermotor beroda dua dengan kapasitas isi silinder lebih dari $250 \mathrm{CC}$;

$>$ Penyerahan kendaraan bermotor berupa kendaraan pengangkutan orang sampai dengan 15 orang termasuk pengemudi dan 7 kendaraan double cabin hasil pengubahan dari kendaraan sasis atau kendaraan pengangkutan barang.

2. PPnBM dibebaskan atas impor atau penyerahan:

Kendaraan ambulan, kendaraan jenazah, kendaraan pemadam kebakaran, kendaraan tahanan, kendaraan pengangkutan umum;

Kendaraan protokoler kenegaraan;

Kendaraan bermotor untuk pengangkutan 10 orang sampai dengan 15 orang termasuk pengemudi yang digunakan untuk kendaraan dinas TNI/POLRI;

* Kendaraan patroli TNI/POLRI.

3. Orang Pribadi (OP) atau Badan yang melakukan impor atau yang menerima penyerahan kendaraan bermotor yang dibebaskan dari pengenaan PPnBM sebagaimana dimaksud butir 2 di atas wajib memiliki Surat Keterangan Bebas (SKB) PPnBM yang diterbitkan oleh Dirjen Pajak c.q. Kepala KPP tempat pemohon terdaftar, sebelum impor atau penyerahan kendaraan bermotor dilakukan

4. Permohonan SKB PPn BM yang diajukan oleh OP atau Badan yang melakukan impor atau yang menerima penyerahan kendaraan ambulan, kendaraan jenazah, kendaraan pemadam kebakaran, kendaraan tahanan, dan kendaraan angkutan umum ke KPP dilengkapi dengan dokumen-dokumen sebagai berikut :

a Surat Kuasa Khusus bila menunjuk pihak lain untuk pengurusan SKB PPn $\mathrm{BM} ; 8$

\footnotetext{
${ }^{8}$ KMK Nomor 355/KMK.03/2003 jo. KEP- 229/PJ/2003
} 
b Fotocopy kartu NPWP

c Surat Keterangan atau dokumen lain yang menunjukkan

d Pengunaan kendaraan dimaksud;

e Surat Pernyataan yang menyatakan bahwa kendaraan dimaksud tidak akan dipindahtangankan atau diubah peruntukannya dan apabila ternyata dipindahtangankan atau diubah peruntukannya, bersedia membayar kembali PPnBM yang dibebaskan ditambah sanksi dengan ketentuan yang berlaku;

f Perjanjian jual-beli kendaraan bermotor yang memuat keteranganketerangan antara lain: - Nama Penjual; - Nama pembeli; - Jenis dan spesifikasi kendaraan yang dibeli;

g Ijin Usaha dan Ijin Trayek yang dikeluarkan oleh instansi yang berwenang (untuk kendaraan angkutan umum selain taksi) atau Persetujuan (Ijin) Prinsip yang dikeluarkan oleh Pemerintah Daerah setempat (untuk taksi);

$\mathrm{h}$ Khusus untuk impor kendaraan bermotor, dilengkapi dengan dokumen impor berupa :

- Invoice;

- Bill of Lading (B/L) atau Airway Bill (AWB);

- Dokumen kontrak Pembelian yang bersangkutan atau dokumen yang dapat dipersamakan;

- 9 Dokumen pembayaran yang berupa Letter of Credit (LlC) atau bukti transfer atau bukti lainnya berkaitan dengan pembayaran tersebut.

5. Permohonan SKB PPnBM dapat ditindak lanjuti dengan syarat bahwa OP atau Badan tersebut tidak mempunyai tunggakan hutang pajak yang telah jatuh tempo, kecuali yang telah mendapat izin untuk mengangsur atau menunda pembayaran pajak. KPP memberikan keputusan dalam jangka waktu 10 hari kerja setelah surat permohonan diterima dengan lengkap.

6. Apabila kendaraan bermotor yang dibebaskan dari pengenaan PPnBM tersebut sebelum lewat jangka waktu 5 tahun sejak impor atau perolehannya dipindahtangankan atau diubah peruntukannya sehingga tidak sesuai dengan tujuan semula, maka PPnBM terutang yang dibebaskan tersebut wajib dibayar kembali dalam jangka waktu satu bulan sejak kendaraan bermotor tersebut dipindahtangankan atau diubah peruntukannya. Dan apabila dalam jangka waktu satu bulan dimaksud 
PPnBM yang terutang tersebut tidak atau kurang dibayar, KPP menerbitkan SKPKB ditambah sanksi sesuai dengan ketentuan yang berlaku

\section{Pengecualian pengenaan PPnBM Kendaraan Bermotor}

1. Impor atau penyerahan kendaraan bermotor berupa: kendaraan (ambulan, jenazah, pemadam kebakaran, tahanan, angkutan umum).

2. Impor atau penyerahan kendaraan yang Protokoler Kenegaraan; kendaraan dinas atau kendaraan patroli TNI/Polri.

Jika kendaraan di atas dikirimkan dalam waktu 5 tahun sejak impor/pembelian, pembayaran PPnBM bersifat opsional dan harus dibayarkan ke kas negara dalam waktu 1 bulan setelah pengiriman kendaraan. Pelanggaran terhadap SKBKB + sanksi sesuai ketentuan yang berlaku.

\section{KESIMPULAN DAN SARAN}

\section{Kesimpulan}

Dari penjelasan di atas dapat ditarik kesimpulan bahwa sistem pemungutan pajak di Indonesia sepenuhnya bersifat self assesment system. Dalam mekanisme pemungutan Pajak Pertambahan Nilai (PPN) dan Pajak Penjualan Atas Barang Mewah (PPnBM) adalah tanda pengenal dari sistem pemungutan pajak penjualan, bukan nama jenis pajak yang mengenakan nilai tambah atas barang atau jasa tertentu yang dikonsumsi. Namun, PPN dipungut pada semua link di jalur produksi dan distribusi sebelum barang atau jasa mencapai tingkat konsumen. Namun pemungutan pajak berjenjang ini berlipat ganda karena pajak yang dibayar oleh Pengusaha Kena Pajak (kredit dibayar) dikembalikan dan persentase beban pajak yang ditanggung konsumen sesuai dengan tarif pajak yang berlaku. Dengan demikian, dapat dikatakan bahwa panjang jalur produksi/distribusi tidak mempengaruhi proporsi beban pajak pada konsumen. Masalah sistem perpajakan yang berlaku di Indonesia dapat ditelusuri kembali ke rendahnya kesadaran hukum masyarakat Indonesia. Wajib pajak memanfaatkan peluang yang ditawarkan oleh sistem self-assessment ini. Undang-undang yang memperlakukan wajib pajak secara self assessment system kurang kesadaran hukum wajib pajak, lemahnya pengawasan, dan belum optimalnya penerapan sanksi bagi wajib pajak yang melanggarnya. Pengawasan sebelumnya belum berjalan maksimal, dan sanksi bagi Wajib Pajak yang ternyata melakukan atau melakukan pelanggaran perpajakan masih sangat lemah. 


\section{Saran}

Berdasarkan uraian penelitian di atas dapat ditarik kesimpulan bahwa Pendapatan pemerintah terbesar, terutama negara kita Indonesia, berasal dari pajak. Pajak memegang peranan yang sangat penting dalam pembangunan suatu negara, khususnya Indonesia. Oleh karena itu, Administrasi Perpajakan perlu dikelola dengan baik dan benar agar masyarakat dapat merasakan manfaatnya. Selain itu, wajib pajak harus membayar pajak secara teratur untuk mencapai pembangunan dan pertumbuhan ekonomi Indonesia. Oleh karena itu, kita warga negara Indonesia perlu memahami hubungan antara pajak Indonesia, tujuan pajak dan tarif pajak agar dapat digunakan dalam kehidupan bermasyarakat dan menjadi warga negara yang sadar pajak.

Sistem perpajakan saat ini (self-assessment system) sudah diterapkan, sehingga perbaikan dan perbaikan dari pihak pemerintah tidak boleh berhenti sampai di sini. Perbaikan berikut perlu dilakukan: Misalnya peningkatan pengawasan, sanksi yang paling besar bagi wajib pajak yang melanggar undang-undang yang ada dan harus memperbaikinya untuk melengkapi hal-hal yang baik tentangnya. Penting juga untuk menyadarkan masyarakat bahwa pembayaran pajak tidak hanya sejalan dengan kewajiban hukum, tetapi juga terkait dengan semangat nasionalisme. Artinya wajib pajak harus atau harus terlibat dalam pembangunan bangsa.

\section{DAFTAR PUSTAKA}

Hadi, S. (2017). Peran Konsultan Pajak Sebagai Partner Direktorat Jenderal Pajak Dalam Sistem Pemungutan Pajak Di Indonesia. Sekolah Tinggi Ilmu Ekonomi Indonesia (STIESIA) Surabaya, 1(1), 1-21.

Indonesia, P. R. (2007). UNDANG-UNDANG REPUBLIK INDONESIA NOMOR 28 TAHUN 2007. In Menkumham.

Rachmad Gesah Mukti Prabowo, SE. Ak, M. (2014). Analisis Pemenuhan Pembayaran Pajak Bumi Dan Bangunan Untuk Meningkatkan Penerimaan Sektor Pajak. 1(1), 103-120.

Setiyaji, G. (2005). Evaluasi Kinerja Sistem Perpajakan Indonesia. Jurnal Ekonomi

Universitas Indonusa Esa Unggul, 7, 1-13.

Witono, B. (2016). Peran Pengetahuan Pajak Pada Kepatuhan Wajib Pajak. Riset Akuntansi Dan Keuangan Indonesia, 7(2), 196-208. https://doi.org/10.23917/reaksi.v7i2.2624 
